\title{
An Analysis of Literacy in Cooperative Economics and the Pancasila Economy in Malang
}

\section{Agung Haryono, Sri Handayani, Syahrul Munir, and Rizza Megasari}

Department of Economic Development, Faculty of Economic, Universitas Negeri Malang

ORCID:

Sri Handayani: http://orcid.org/0000-0002-4471-6153

\section{Abstract}

As current and future economic actors, the younger generation needs to be provided with a complete understanding of the economic system that should be enforced in Indonesia. Until now, the implementation of the economic system has not met the expectations of the mandate of the 1945 Constitution. One of the mandates affirmed in the Constitution is the role of cooperatives that play an important role in the national economy. But as reform progresses, the role of cooperatives has deteriorated

Corresponding Author: Agung Haryono sri.handayani.fe@um.ac.id

Published: 14 July 2021

Publishing services provided by Knowledge E

(c) Agung Haryono et al. This article is distributed under the terms of the Creative Commons Attribution License, which permits unrestricted use and redistribution provided that the original author and source are credited.

Selection and Peer-review under the responsibility of the IRCEB Conference Committee.

\section{G OPEN ACCESS} compared to the previous period. This descriptive qualitative research was conducted with students of the Faculty of Economics in Malang Raya, to determine their literacy in cooperative economics and the Pancasila economy. The results showed that the literacy of the students was good.

Keywords: co-operative economic literacy, Pancasila economy

\section{Introduction}

High economic growth is accompanied by an increase in social inequality, indicating that the actual economy operating in Indonesia is not quite right. Because the rich will get richer and the poor will remain poor. The system that operates seems to have justified the opinion that the Indonesian economic system adheres to a Neo-liberal system which is clearly incompatible with the spirit and characteristics of the Indonesian nation which upholds the values of simplicity, kinship and mutual cooperation.

Cooperatives as the pillars of the Indonesian economy are expected to be able to cut economic inequality, because the cooperative business is in accordance with the characteristics of a collective Indonesian society and is based on social capital. Therefore, cooperatives are given the authority as one of the formal sector economic actors in addition to State-Owned Enterprises (BUMN) and Private-Owned Enterprises (BUMS) in promoting economic development. 
However, in reality, the contribution of cooperatives to Gross Domestic Product (GDP) is very far compared to BUMN and the private sector. Cooperatives are in the last rank on the basis of prevailing prices $(A D H B)$ which are still relatively small, namely below 5 percent compared to other economic actors. Despite the increasing trend of contribution, in 2014 the contribution of cooperatives was only $1.71 \%$, increasing to 3.99\% in 2016, even in 2017 it reached 4.48\%. That was the explanation of the Minister of Cooperatives and SMEs in Media Indonesia (Media Indonesia: 2017).

In 2019, Cooperatives in East Java play a very important role and become the basis for social economic development. This condition is shown by the number of cooperatives which reached 34,043 units even though there were 9,626 units or 20 percent including the less productive category. The total assets of cooperatives in East Java reach IDR 34 trillion and are capable of absorbing labor as many as 62,000 people, as conveyed by the Head of the East Java Cooperatives and UKM Service. (Jatim News: 2019).

Cooperatives currently have a bad image in the eyes of the community, especially the younger generation. Because there are many cases of fraud committed by fake cooperatives such as fake investments under the guise of cooperatives. For example, the Pandawa Cooperative, whose victims reached thousands. In addition, there are still 11 problematic cooperatives that are frozen by the Ministry of Cooperatives, namely: Cassava Agro Cooperative (Bogor), Pandawa Mandiri Group Savings and Loans Cooperative (KSP) (Depok City), KSP Wein Sukses (Kupang), Sharia Financing Savings and Loan Cooperative (KSPPS).) BMT CSI Syariah Sejahtera (Cirebon). Then, KSPPS BMT CSI Madani Nusantara (Cirebon), Indonesian Cooperative (Malang), Bintang Abadi Sejahtera Koperasi (Bogor), Bermuda Triangle Cooperative (Gowa). Furthermore, the Red and White Cooperative (Tangsel), the Bank Bumi Daya Cultural Cooperative (Riau), the Cooperative Must Succeed Together ( Jambi), and the Karya Putra Alam Cooperative (Gunung Putri, Bogor). (Kompas: 2017). Various problems and the many cases that shackle cooperatives add to the negative image of cooperatives among the younger generation, especially students, as evidenced by the lack of students who are actively involved in managing student cooperatives. However, after the successful implementation of the student cooperative jamboree in Malang in September 2019, the activity of student cooperatives in Malang began to develop, among others, it was proven by the activity of several Kopma who had suspended animation such as Kopma UB (Prasetya: 2019). This moment is a good opportunity to explore the understanding of economic literacy of cooperatives and Pancasila economics in student cooperative members throughout Malang Raya. 


\section{Research Methods}

This research is a qualitative descriptive study. The method used is a survey method via google form. The objectives of this survey are:1) to explore understanding of cooperative economic literacy and 2) to explore understanding of Pancasila economy for members of student cooperatives throughout Malang Raya. Respondents in this study were 48 students. Variables and indicators to measure the economic understanding of Pancasila, namely: 1) the identity of the cooperative which has indicators including: a) cooperative motives, b) cooperative values, c) cooperative principles, d) cooperative foundation, e) cooperative function and role; 2 ) Cooperative organizations with indicators, namely: a) understanding of the AD / ART of cooperatives, b) Functions of Member Meetings, c) Determination and Distribution of SHU, d) role of members; 3) Cooperative capital with indicators a) cooperative own capital, b) Ioan capital, c) calculation mechanism and SHU distribution; 4) Cooperative businesses with indicators a) types of cooperative businesses, b) cooperative managers, 5) The role of cooperatives in the Pancasila Economy, which consists of indicators, namely: a) the essence of Pancasila economy, b) the principle of cooperatives in Indonesia, c) The role of cooperatives in Indonesian economy.

The results of the survey will be analyzed data. The following research method can be seen in Figure 1 below.

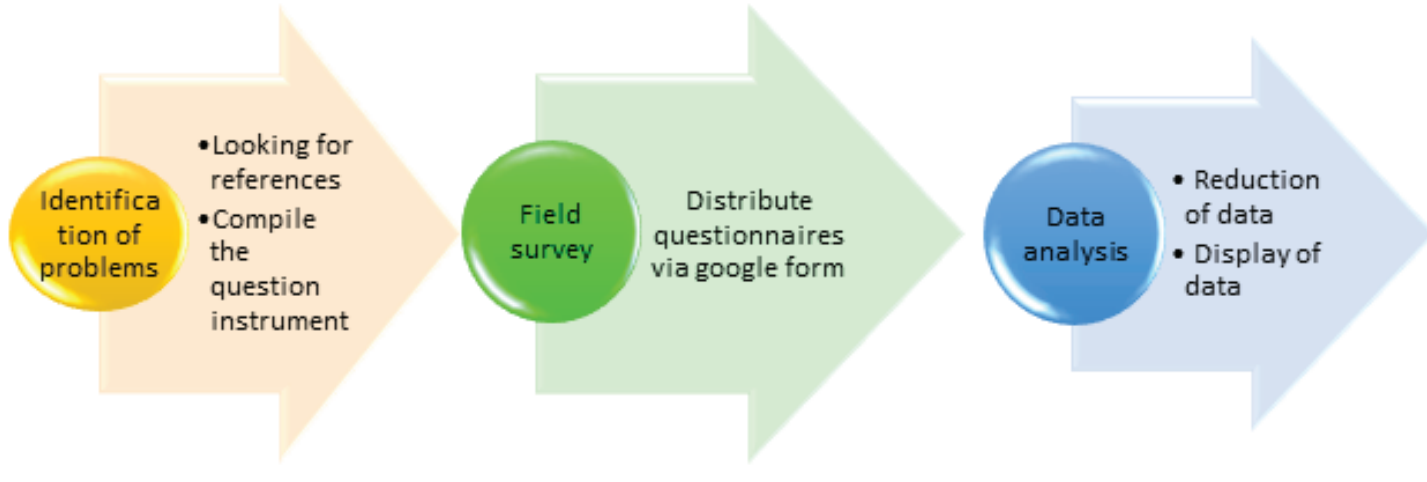

Figure 1: Research Methods

Based on Figure 1, it can be seen that there are 3 stages in carrying out research activities, namely: 1) problem identification, 2) field surveys, and 3) data analysis. Respondents who were surveyed in this activity came from Ma Chung University, UIN Maulana Malik Ibrahim, Kanjuruhan University, Malang State University, and Malang Muhamadiyah University. 


\section{Research Result and Discussion}

After analyzing the data from 48 survey respondents according to the research method, it can be seen that the results of this study include::

1) Understanding of cooperative economic literacy cooperative members students in Malang Raya

\section{A. Understanding of cooperative identity}

To find out the members' understanding of cooperative identity, it can be seen from the motives of respondents to become cooperative members, understanding of cooperative members about cooperative values, cooperative principles, understanding of the foundation of cooperatives and knowledge and understanding of the functions and roles of cooperatives. From the survey that has been carried out, it can be seen in Figure 2 below.

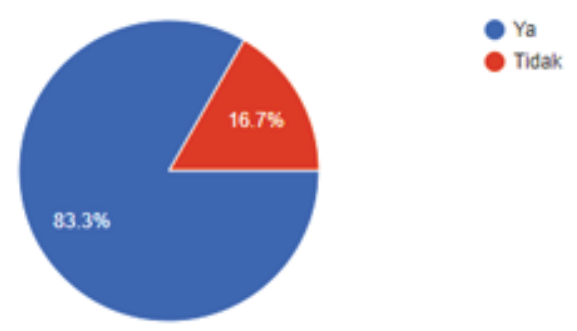

Figure 2: Understanding the Definition of Cooperative

Figure 2 shows that the respondents already have an understanding of the definition of a good cooperative. This is proven by $83.3 \%$ of respondents who have understood the definition of a cooperative in accordance with the Cooperative Law or the results of the ICA Congress. With these results, the role of student cooperatives is sufficient to provide an understanding of the identity of the cooperative. In line with Sukidjo, et.al (2016) from the results of research conducted in vocational school students on Kopsis, it is stated that many benefits are obtained from school cooperative development activities. Students who are active in school cooperative activities may have the ability in the form of knowledge, attitude, and skill corresponding values in the cooperative. If cooperative education is elaborated in a more characteristic form, it opens up opportunities for students to become human beings who have the ability, knowledge, attitudes, and skills to cooperate in accordance with the demands of the value of the cooperative itself. 
Based on a survey conducted by students' motivation to become members of KOPMA, there are various kinds, including:

1) Learn entrepreneurship and excel at Kopma to get a scholarship

2) To seek experience

3) To learn in organization, leadership, and entrepreneurship

4) Want to know and learn more about how to manage the economy based on family principles

5) To learn and develop social-based entrepreneurship

6) Want to learn more about cooperatives and adjust to the scientific field that fits the study program.

7) Seeking organizational knowledge, applying marketing knowledge, realizing the dream of becoming an entrepreneur

8) Want to proceed in a cooperative because since high school students have started joining the cooperative, school students continue at the Univ Malang Student Cooperative. Can get a lot of experience, relationships, and also economic benefits.

9) Likes cooperative organizations and is interested in cooperatives

10) Want to learn a lot about business in cooperatives, buying and selling, socializing with many people.

11) As a forum for learning entrepreneurship based on mutual cooperation

12) Make friends and earn SHU

13) Helping make ends meet

14) Can save for future needs and build relationships with members

15) Get to know financial institutions other than banks

16) To get loans and get business capital and income.

The survey results are in line with Rahman (2019) who conducted research on members' decisions to become cooperative members in Islamic cooperatives in Banjarmasin, showing that there are 2 motivational motives, namely intrinsic and extrinsic. The intrinsic motivation for its implementation is in accordance with Islamic law and avoiding usury, as well as from one's own desire to become a member and extrinsic motivation due to low administrative costs, services, security, strategic location, and advice from outside parties. Another study, namely Tondok (2016), the relationship between internal motives and participation to become members of cooperatives is inversely related, namely an increase in internal motives will reduce employee participation to become members of Employee Cooperatives, on the other hand a decrease in internal motives 
will increase employee participation to become members of employee cooperatives. Contemplating the relationship between external motives and participation in becoming members of cooperatives is unidirectional, namely increasing external motives will increase employee awareness of participating in employee cooperatives, on the other hand a decrease in external motives will also reduce employee participation to become members of employee cooperatives.

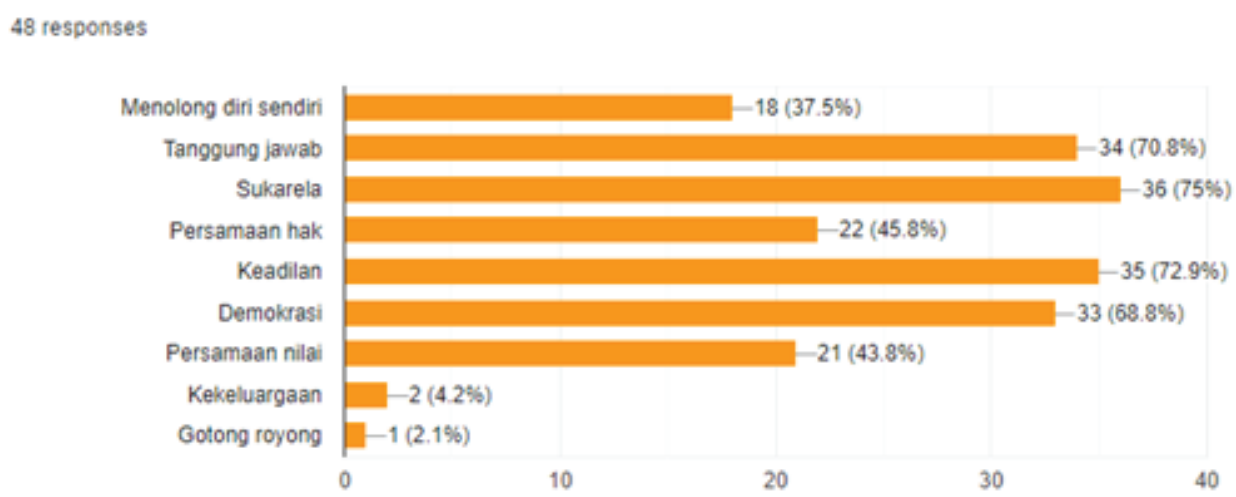

Figure 3: Values of the cooperative

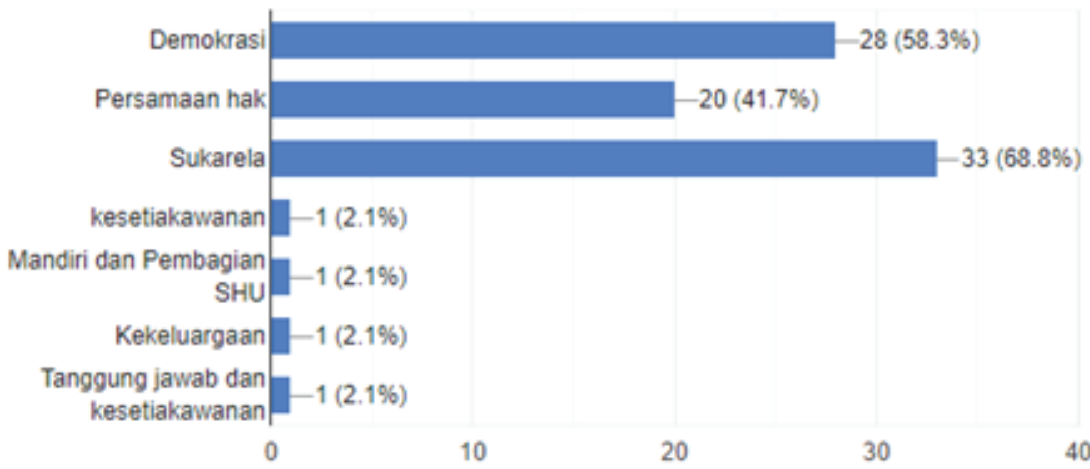

Figure 4: ICA cooperative principles

Figures 3 and 4 show that KOPMA members already understand well the values and principles of cooperatives. This is indicated by an average of more than 30 respondents who correctly stated the values and principles of the cooperative. Cooperative values which consist of the basic values and values of cooperative members. Basic values consist of kinship, self-help, responsibility, democracy, equality, justice, and independence. Meanwhile, the values of cooperative members include honesty, openness, responsibility and concern for others. Based on Law Number 25 of 1992 concerning Cooperatives, the principles of cooperatives are: Membership is voluntary and open. Management is carried out democratically. The distribution of the remaining 
income is carried out fairly in proportion to the amount of business services of each member. With an understanding of the values and principles, it shows that the millennial generation, namely students who are members of KOPMA (Student Cooperative), have understood cooperative organizations. This is in line with Kristian (2020) who conducted research on innovation in cooperative organizations, namely the need for rebranding, namely Mi-Co (Millennial Cooperative) which is in accordance with the principles, values, and identity of cooperatives in their operations as well as millennial characteristics.

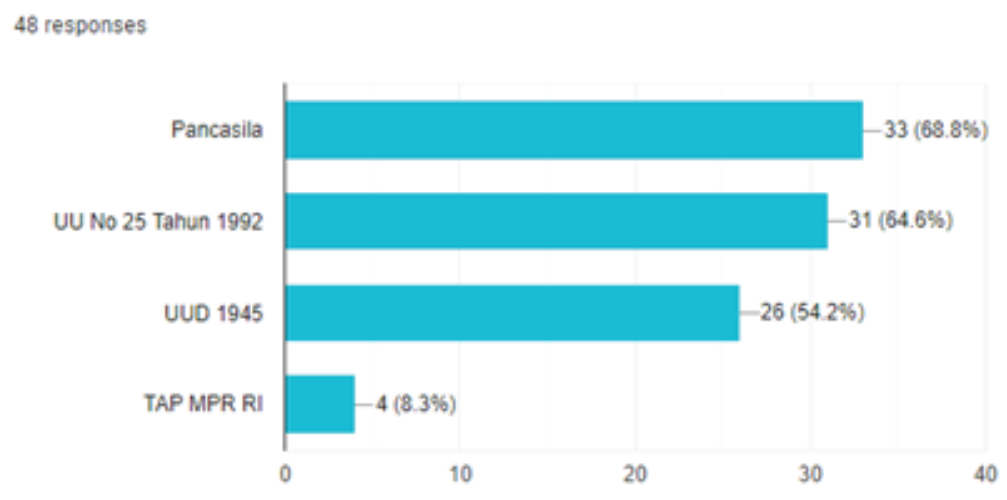

Figure 5: Cooperative foundation

48 responses

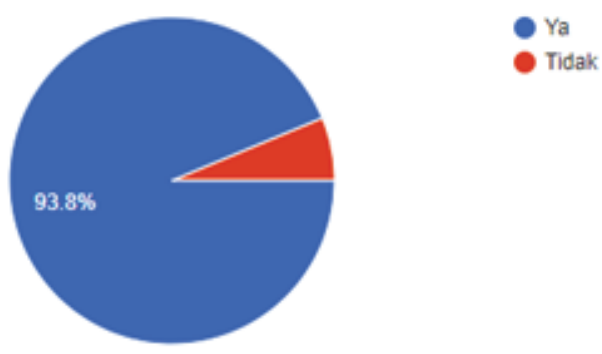

Figure 6: Students' understanding of the functions and roles of cooperatives

Based on figures 5 and 6 , it shows that the respondents have a good understanding of the basis and function and role of the cooperative. This shows that more than 30 respondents answered correctly about the foundation of the cooperative and as much as $93.8 \%$ of respondents understand the function and role of the cooperative.

\section{B. Cooperative Organization}

Based on the survey results, an understanding of cooperative organizations can be seen from: understanding of the AD / ART of cooperatives, the Function of Member Meetings, Determination and Distribution of SHU and the role of member

Based on figures 7 and 8 regarding AD / ART as many as $89.6 \%$ of students correctly stated the definition of primary cooperative and only 7 respondents incorrectly 


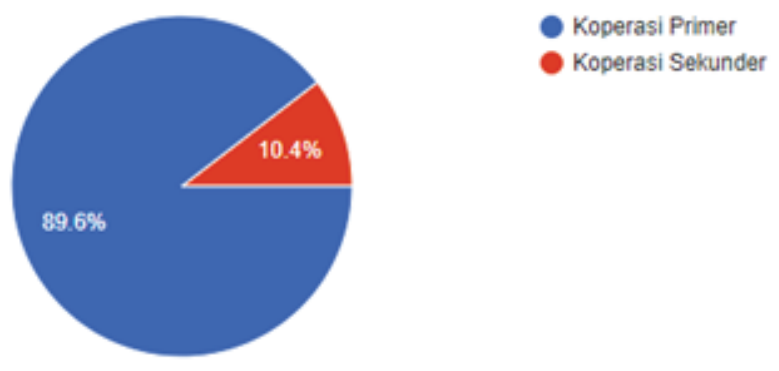

Figure 7: Understanding of Primary Cooperative

48 responses

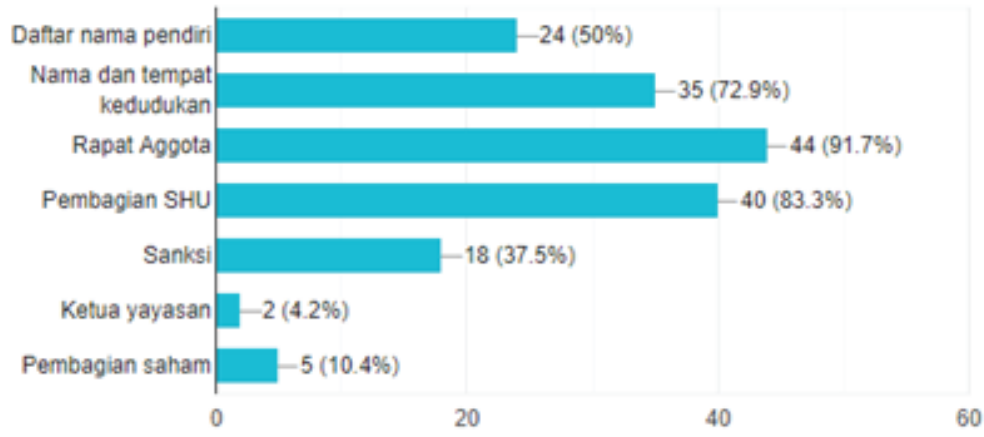

Figure 8: Contents of the cooperative regulations

mentioned the contents of the AD / ART. This shows that the existence of the AD / ART KOPMA has been running in accordance with the mandate of the Cooperative Law. In line with Dewi (2018) the position of AD / ART is not only a formality in establishing cooperatives but $A D$ / ART also as a support and support in effectiveness and effectiveness. cooperative work mechanism.

48 responses

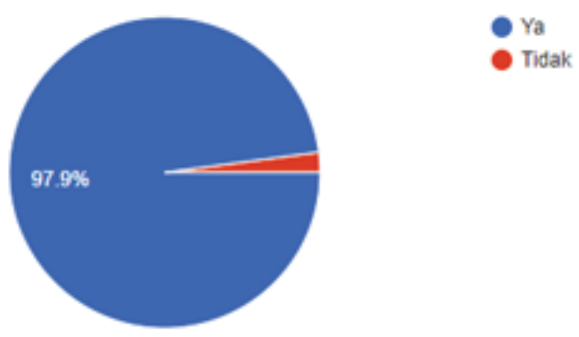

Figure 9: Functions and Roles of Member Meetings

Figures 9 and 10 show that $97.9 \%$ of KOPMA members stated that they understood well about the annual Member Meeting and Member Meeting. In line with research by 
48 responses

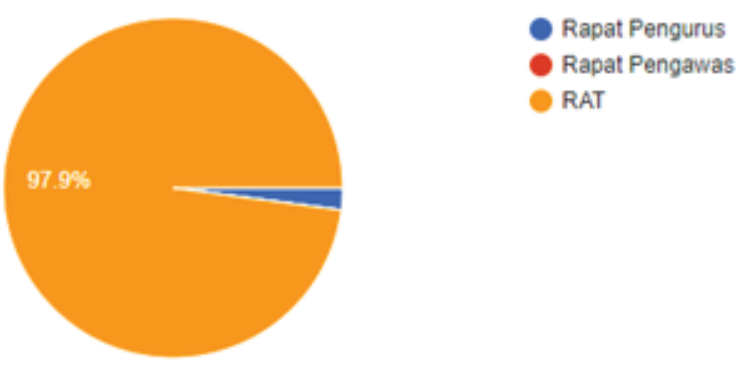

Figure 10: Functions and Roles of RAT (Annual Meeting of Members)

Suwetty (2017) Values, cooperative principles have a significant positive effect. This means that the regression coefficient of the cooperative values b1 is 0.58 , which means that any increase in the values of the cooperative will increase the quality of the Annual Member Meeting by 58.4\% (assuming other variables are constant), while the coefficient of cooperative principles b2 amounted to 0.770 , which means each an increase of Principles pri nsip cooperative will increase Kua litas RAT amounted to 77.0\% (by assuming other variables constant).

48 responses

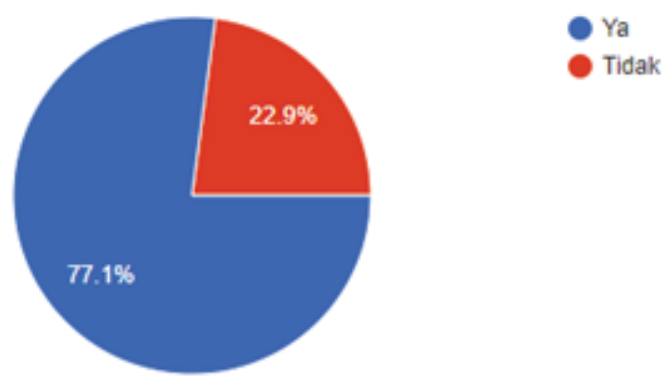

Figure 11: Cooperative ownership

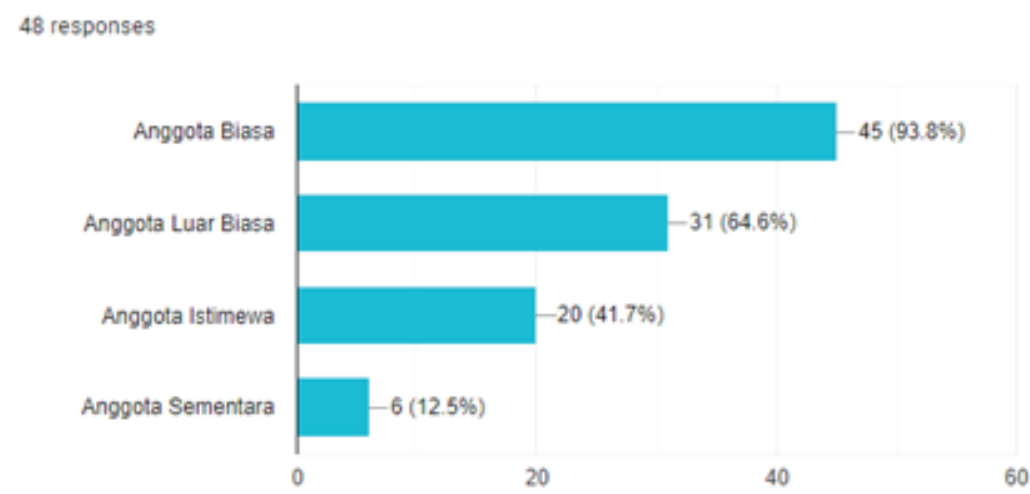

Figure 12: Understanding of the Types of Cooperative Members 
48 responses

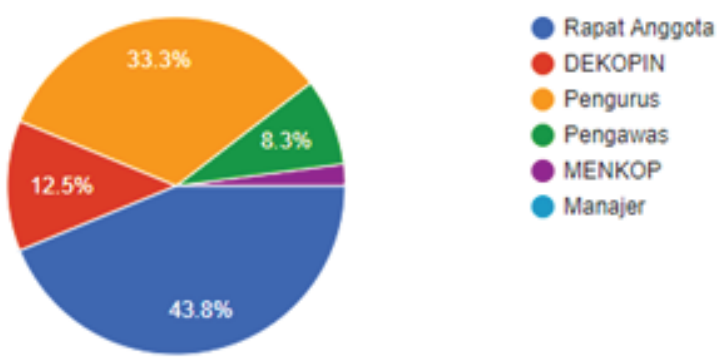

Figure 13: Cooperative Organizational Tools

Organizational tools that have been understood by KOPMA members can be said to be good. This can be seen from Figure 11 as much as $77.1 \%$ understands cooperative ownership and based on Figure 12, more than 30 respondents understand the classification of cooperative members and based on Figure $13,43.8 \%$ of respondents understand the cooperative organizational instruments that come from member meetings. Although there were still mistakes, The Menkop and Dekopin were considered as cooperative organizational instruments.

C. Cooperative capital with indicators a) cooperative own capital, b) loan capital, c) calculating and distributing SHU mechanics

48 responses

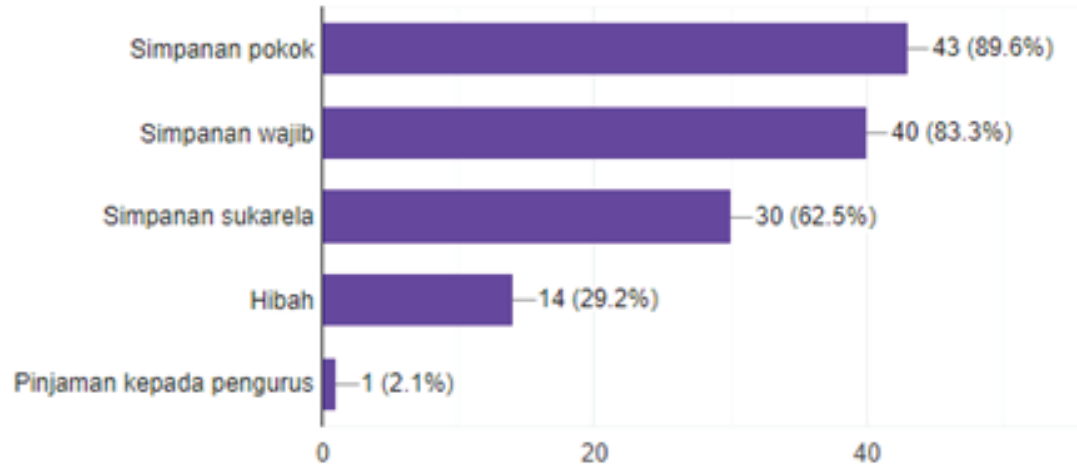

60

Figure 14: Cooperative Capital

D. Cooperative businesses with indicators a) types of cooperative businesses, b) cooperative managers,

1) Understanding Pancasila economics for members of student cooperatives throughout Malang Raya 
48 responses

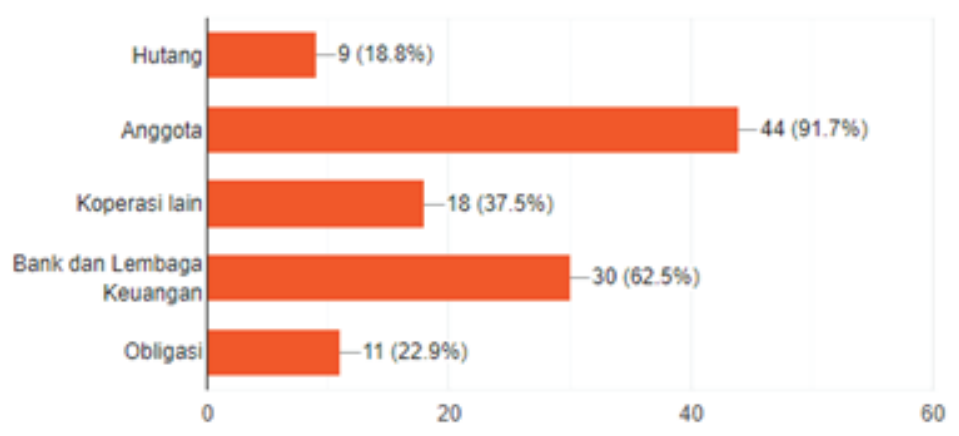

Figure 15: Cooperative Loan Capital

yaitu ....

48 responses

30

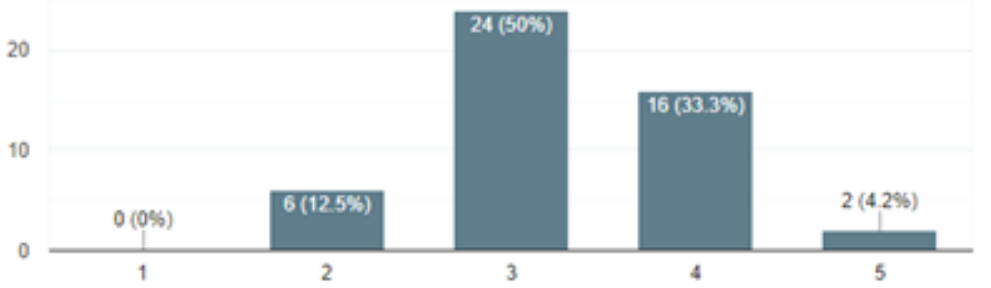

Figure 16: The mechanism for calculating and distributing SHU

48 responses

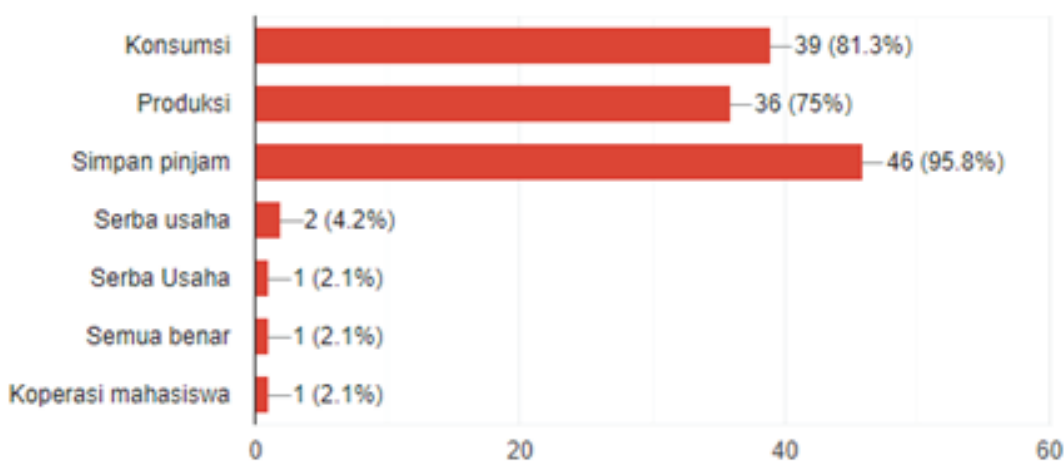

Figure 17: Cooperative Enterprises

2) Understanding the role of cooperatives in Pancasila Economy 
48 responses

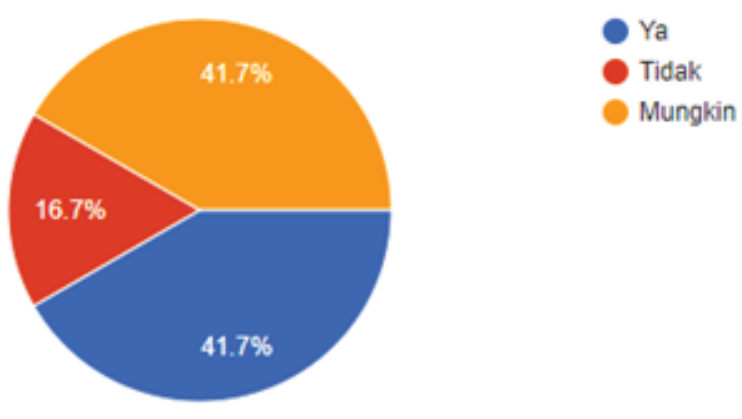

Figure 18: Appointment of the cooperative manager

48 responses

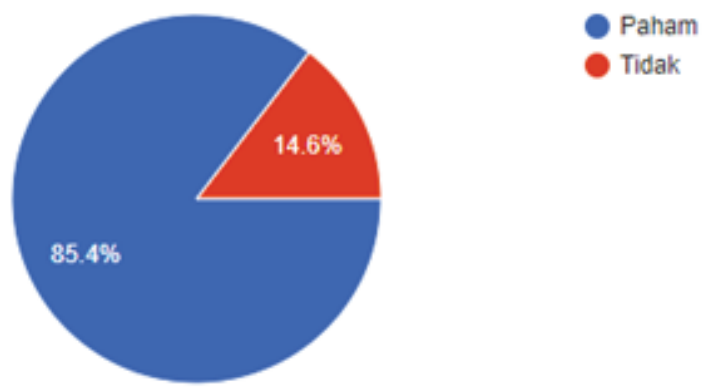

Figure 19: The role of the cooperative organization

48 responses

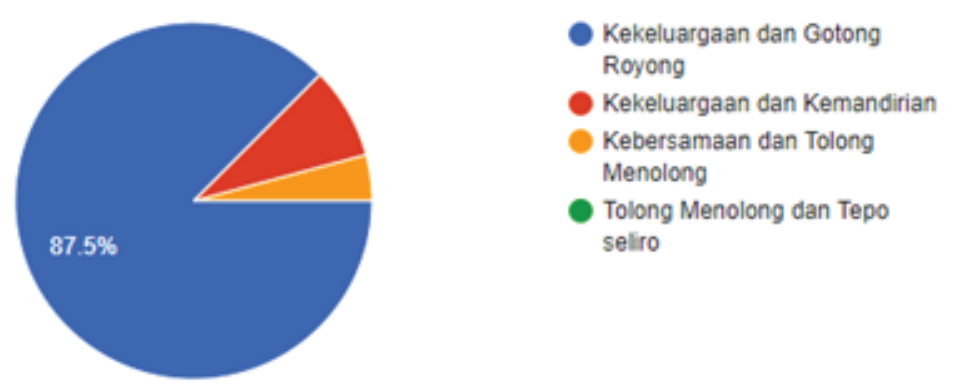

Figure 20: Principles of Cooperatives

\section{Conclusion}

Based on the discussion, it can be concluded that 1) The understanding of economic literacy of student cooperative members is good. This is in accordance with a survey from students about the identity of cooperatives, cooperative organizations, cooperative 


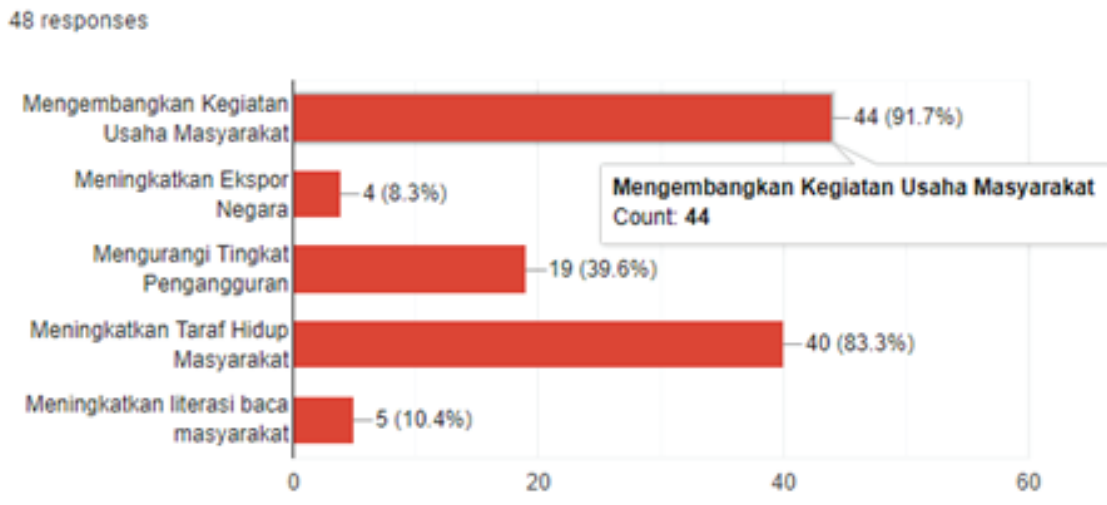

Figure 21: The role of cooperatives in the Indonesian economy

capital and cooperative businesses that have been controlled by KOPMA students; 2) The understanding of Pancasila economics for student cooperative members is good. This is indicated by as many as 38 respondents showing an understanding of the economic principles of cooperatives and the role of cooperatives in the economy

\section{References}

[1] OCDC. (2018). Report on the Results of the Indonesian Economic Survey, Organization for Economic Co-operation and Development. Retrieved from http economic-forecast-summary-indonesia-oecd-economic-outlook.pdf. [4 January 2021]

[2] BPS. (2019). Indonesian Central Bureau of Statistics. Retrieved from bps.go.id. [4 January 2021]

[3] Media Indonesia. July (2017). Retrieved from https://mediaindonesia.com/read/ detail/171760-kontribution-koperasi-men Increase.[4 January 2021]

[4] Jatim News. Mei(2019). Retrieved from http://kominfo.jatimprov.go.id/read/general/ year-2019-cooperatives-in-EastJava-reaching-34-thousand-units. [ 4 January 2021]

[5] Kompas. (2017, October). Retrieved from https://ekonomi.kompas.com/read/ 2017/10/24/132026626/kemenkop-and-ukm-oversee-12-problem-cooperativecooperatives. [4 January 2021]

[6] Prasetya. (2019) Retrieved from https://prasetya.ub.ac.id/berita/KOPMA-UB-RebornGandeng-Alumni ${ }^{23489-i d . h t m l ~[4 ~ J a n u a r y ~ 2021] ~}$

[7] Law No. 25 of 1992, concerning Cooperatives.

[8] Banu, B. S., Haryono, A. and Winarno. (2010) Article 33 of the 1945 Constitution in a Cultural Perspective of the Basic Values of Pancasila. Malang: UM Press. 
[9] Haryono, A. (2015). Study of the Effectiveness of Increasing Social Economy through Traditional Markets with Modern Markets. Pasuruan Regency: Research and Training Development Agency.

[10] Riyanto, T. (2004). Ki Hajar Dewantara's Thoughts on Education. Retrieved from http: //bruderfic.or.id/h-59/pemikiran-ki-hajar-dewantara-tentang-pendPendidikan.html. [4 Jnauary 2021]

[11] Beaudin, L., et al. (2017). Enhanching the Teaching of Introductory Economics With a Team-based, Multi-Section Competition. The Journal of Economics Education, vol. 48, issue 3, pp. 16 - 175.

[12] LP2M UM. (2016). LP2M Research Strategic Plan for 2016 - 2020. Malang: State University of Malang.

[13] Gall, M. D., Gall, J. P. and Borg, W. R. (2003). Educational Research: An Introduction. Boston: Pearson Education.

[14] Sukidjo, S et al. (2016). School Cooperatives as a Place for Student Character Development. Journal of Economia, vol. 12, issue 2. pp 1-16

[15] Rahman, A. (2019). Motivation Analysis of the Decision to Become a Member of the Arrahmah Islamic Cooperative in Banjarmasin (Doctoral Thesis, UIN Antasari Library, Banjarmasin, 2019).

[16] Tondok. (2016). Relationship between Internal Motives and External Motives for Employee Participation as Members of the Kaltim Prima Coal Employee Cooperative. Prediction Journal, vol. 4, issue 4,pp 1-16

[17] Smart Class. March (2019). Retrieved October 12, 2020 from https://www. kelaspintar.id/blog/tips-pintar/ekonomi-koperasi-indonesia-seperti-apa-2200/\#: : text=Nilai\%20dasar\%20koperasi\%20antara\%20lain,dan\%20kepedulian\%20pada\% 20people\%20other.

[18] Kristian KM, et al. (2020). Mi-Co (Millennial Cooperative): Millennial Era Cooperative Rebranding Solution to Meet the 2030 Demographic Bonus. Scientific Journal of Accounting and Finance, vol. 2, issue 2. PP 88-110.

[19] Dewi, R. C. (2018) Assistance in Making AD / ART in Order to Improve the Working Mechanism of Cooperatives at the Miagan Village Swastika Women's Cooperative, Mojoagung District, Jombang Regency. Journal of Community Service, vol. 3, issue 1.pp 25-34. 